\title{
Obituary
}

\section{Professor D. G. Millar}

David Gavin Millar, Foundation Professor of Human Reproduction and Obstetrics at the University of Southampton, died on March 4 at the age of forty-one. The son of a general practitioner, he was born in Durham and educated at Durham School. He studied medicine at the University of Durham (at Newcastle upon Tyne), graduating with honours in 1952. He was elected FRCS in 1959 and MRCOG in 1962.

As an undergraduate he won the Gibson Prize in Obstetrics and the British Medical Association essay competition for medical students in 1952-the subject of his essay was "The Training of the Student in Personal Relationships between Doctor and Patient". After a distinguished undergraduate career and service in the RAMC he returned to Newcastle upon Tyne where he trained first as a general surgeon and then as a gynaecologist. He soon secured the reputation of a highly skilled and sympathetic clinician and on this sound foundation he built his research interests. As Luccock Research Fellow from December 1959 to March 1961 he mastered the use of the digital computer and produced programs for the handling of data from the community study of obstetrics in the City of Newcastle upon Tyne. This personal experience of the application of computer techniques to research in obstetrics led to his taking a serious and lasting interest in the application of the computer to a wide variety of problems in medicine and to his appointment to a number of important medical committees. One of the highlights of the 17th British Congress of Obstetrics and Gynaecology in 1965 was his paper on the contribution of the computer to research in obstetrics. David Millar was one of the few medical men who really understood and could talk authoritatively on the subject. $\mathrm{He}$ also contributed notably to the success of the new undergraduate curriculum in Newcastle upon Tyne. He understood the need to break away from the narrow, "departmental" approach to teaching with its tendency to present medicine as a series of disjointed and unrelated specialties. He was, in fact, a strong supporter of the integrated pattern of teaching and argued convincingly that human reproduction, touching on so many disciplines, lent itself to this approach. In Newcastle he helped build up a library of objective multiple choice questions for use in the final examinations and his complete grasp of the computer analysis of such questions led in time to his appointment as chairman of the committee appointed by the Royal College of Obstetricians and Gynaecologists to supervise the setting and marking of the new MRCOG (Part 1) multiple choice question paper.

A major research interest, which extended over many years, was the effect of certain obstetric events on the physical and intellectual development of children. Here he collaborated principally with Dr Gerald Neligan in the Department of Child Health and several important papers were delivered to societies in the United Kingdom and America. $\mathrm{He}$ showed, for example, that such obstetric complications as vaginal breech delivery and placenta praerin had a significantly adverse effect on the IQ of surviving children at the age of 5 years.

His recent appointment to the chair in Southampton seemed to set the seal on what was to be a brilliant career and his tragic death at such an early age is a grievous loss to the subject and Southampton. Already David Millar had established a national reputation and had he lived he would certainly have reached the front rank of his chosen specialty. $\mathrm{He}$ is survived by his wife (also a doctor), two sons and twin daughters.
Announcements

\section{University News}

Professor Gordon Atherley has been appointed to the newly established chair of safety and hygiene in the University of Aston in Birmingham.

Dr E. N. Corlett has been appointed to the newly established chair of industrial ergonomics in the University of Birmingham and Dr D. G. Walker has been appointed to a chair of biochemistry.

Dr C. Andrew has been appointed to the chair of mechanical engineering, Dr J. F. Mitchell to the chair of pharmacology and Dr R. D. Milne to the chair of theoretical mechanics, all in the University of Bristol.

Dr D. J. Osborne, deputy director of the ARC Unit of Developmental Botany, has been elected to a fellowship at Churchill College, University of Cambridge.

Sir Frederick Warner has been appointed chairman of the council of the School of Pharmacy, University of London, in succession to Sir Harry Jephcott.

Mr L. C. B. Gower will succeed Professor Kenneth Mather as vice-chancellor of the University of Southampton.
Professor T. A. Bennet-Clark, University of East Anglia, has been appointed Royal Society visiting professor in the Department of Botany, University of Zambia.

\section{Miscellaneous}

Dr George R. Hill, dean of the College of Mines and Mineral Industries at the University of Utah, will be the 1971 recipient of the $\mathrm{H}$. H. Storch award for research on coal chemistry, presented by the Fuel Division of the American Chemical Society.

\section{International Meetings}

May 24, Environmental Influences on Reproduction, London (Dr R. E. Lister, Inveresk Research International, Inveresk Gate, Musselburgh, Midlothian).

May 31-June 2, Canadian Chemical Conference, Halifax, NS (The Chemical Institute of Canada, 151 Slater Street, Room 906, Ottawa 4, Ontario, Canada).

June 6-11, European Rheumatology Congress, Brighton (Congress Secretariat, c/o Arthritis and Rheumatism Council, 8-10 Charing Cross Road, London WC2). June 10-11, Metabolism and Disease, Ottawa (Dr R. S. Meldrum, Food and Drug Directorate, Tunney's Pasture, Ottawa 3, Ontario, Canada).
July 5-9, Introductory Course in Tropical Hygiene, London (Ross Institute of Tropical Hygiene, London School of Hygiene and Tropical Medicine, Keppel Street (Gower Street), London WC1E 7HT).

July 8-9, Behavioural Aspects of Parasite Transmission, London (The Executive Secretary, Linnean Society of London, Burlington House, Piccadilly, London W1V 0LQ).

August 16-28, Organizations and Computers, Dubrovnik (L. Radanovic, Centre of Advanced Studies, PO Box 356, Belgrade, Yugoslavia).

September 9-12, Taxonomy and Phytogeography of Higher Plants in Relation to Evolution, Manchester (Dr C. A. Stace, Department of Botany, University, Manchester M13 9PL).

September 13-16, Liquid Scintillation Counting, Brighton (Mr M. A. Crook, Society for Analytical Chemistry, 9-10 Savile Row, London W1X 1AF).

September 14-16, Quinone Chemistry, Aberdeen (Dr L. Batt, Department of Chemistry, University of Aberdeen, Meston Walk, Aberdeen AB9 2UE).

October 13-18, The Protection of Nature and its Environment, Rouen (ProtechnaCOMET, 48 Quai de Paris, 76 Rouen, France). 


\section{British Diary}

\section{Tuesday, April 13}

Styling for Motor Vehicles (7.30 p.m.) Mr D. Bache, Society of Environmental Engineers, in the Mechanical Engineering Department, The University, Birmingham.

Tension Levelling (6 p.m. discussion) Institution of Mechanical Engineers, Applied Mechanics Group, jointly with the South Wales Branch, at Swansea.

\section{Wednesday, April 14}

Current Research in Crystallography (three-day conference) Institute of Physics and the Physical Society; and the Chemical Society, at the University of Manchester Institute of Science and Technology, Sackville Street, Manchester.

Electrical Conduction in Organic Solids (general discussion, three days) Faraday Society, in the Chemistry Department, University of Nottingham, University Park, Nottingham.

Externally Pressurized Bearings (two-day conference) Institution of Mechanical Engineers, Tribology Group, jointly with I.Prod.E., at Coventry.

\section{Thursday, April 15}

Development of Electrical and Electronic Systems during Flight Testing of New Aircraft (6 p.m. discussion) Institution of Electrical Engineers, at Savoy Place, London WC2.

Thermal Analysis with special reference to Microtechniques (two-day meeting) Society for Analytical Chemistry, at the Nobel Division, ICI Ltd, Ardeer, Ayrshire.

\section{Friday, April 16}

Engineering Science in Schools (2 p.m. discussion) Institution of Electrical Engineers, at Savoy Place, London WC2.
The Effective Training of Professional Engineers as Managers (5.30 p.m.) Mr P. H. L. Thomas, Institution of Electrical Engineers, at Savoy Place, London WC2.

\section{Monday, April 19}

HV Overhead Transmission Lines (6.30 p.m.) Mr G. Orawski, Institution of Electrical Engineers, London Graduate and Students Section, at Savoy Place, London WC2.

On the Relativity of Time (5.30 p.m.) Mr A. Trieder, British Society for the Philosophy of Science, in the Joint Staff Common Room, University College London, Gower Street, London WC1.

Semiconductor Circuit Design (vacation school, five days) Institution of Electrical Engineers, at the University College of Swansea, South Wales.

\section{Reports and Publications}

not included in the Monthly Books Supplement

\section{Great Britain and Ireland}

Teachers and Youth Workers: a Study of Their Roles. (Schools Council Working Paper No. 32.) Pp. 128. (London: Evans/Methuen Educational, 1971.) 57p net.
The Carnegie United Kingdom Trust. Fifty-
seventh Annual Report, 1970. Pp. viii + 76. Dunferm. 1ine, Fife: The Carnegie United Kingdom Trust,

Fabian Tract No. 406: Divide and Rule: The Industrial Relations Bill. By Giles Radice and J. O. N. Vickers. Pp. 20. (London: Fabian Society, 1971.) Fiora of Tropical East Africa. Edited by E. MilneRedhead and R. M. Polhill, Hamamelidaceae. By B. Verdcourt. Pp. 5. 10p. Flagellariaceae. By D. M. Napper. Pp. 3. 10p. Juncaginaceae. By D. M. Napper. Pp. 3. 10p. Lecythidaceae. By G. R. W. Sangai. Pp. 6. 10p. Phytolaccaceae. By R. M. Polhill. Pp. 8. 15p. Oxalidaceae. By Chris tine H. S. Kabuye. Pp. 21, 25p Geraniaceac. By . O. Kokwaro. Pp. 23. 25p. Plantaginaceae. B B. Verdcourt. Pp. 7 15p. Cabombaceae. By B Verdcourt. Pp. 3. 10p. Typhaceae. By D. M Napper. Pp. 5. 10p. Annonaceae. By B. Verdcourt. Pp. 132. 100p. (London: Crown Agents for Overse (15) Administrations, 1971.) Proceedings of Conference on Fumeless Refining and 18th September, 1970. (Sheffield. St in Sheffield, 18th September, 1970. (Sheffield: Steel Casting $\$ 13$.

Curriculum Innovation in Science. By Professo K. W. Keohane. (Inaugural Lecture 4th November 1969.) Pp. 11. (London: Chelsea College, University
of London, 1971.)
Heriot-Watt University, Edinburgh. Annual Report 1969/1970. Pp. 86. (Edinburgh: Heriot-Watt University, 1971.)
University of Hull. Occasional Papers in Geography. No. 9: A Scheme for Hillslope Analysis. P. Initial Considerations and Calculations. By A.F. Hillsiope. ix +76 . 75p. No. 17. A Scheme for . A ences. By A. F. Pitty. Pp. viii +56. 1 . (Hull:
The University, 1969 and 1970.) Some Methods for the Statistical Analysis of Samples of Benthic Invertebrates. By J. M. Elliott. (Scientific Publication No. 25.) Pp. 144. (Ambleside: Freshwater Biological Association, 1971.) 95p. [163 Chatham House and PEP. European Series No. 16: Agricultural Policy and the Common Market. By John Marsh and Christopher Ritson. Pp. 199. (London: Chatham House and PEP, 1971.) Luffield's Benefaction University of Oxford. Lord Nuffield's Benefaction
for Advance of Medicine-Report for 1968/69. Pp. 6 . Supplement No. 2 to the University Gazette, Vol. ci, Jan. 1971.) (Oxford: The University, 1971.) 25p. [163 Tate and Lyle, Ltd. Group Research and Development Annual Report for 1970. Pp: 71. (Keston, Kent: Tate and Lyle, Ltd, 1971.) Energy Resources for Western Europe: Present Situation and Future Prospects. Pp. 37. (London: [173 Abstraction in Science and Morals. By Professor Stephan Körner. (The Twenty-fourth Arthur Stanley Eddington Memorial Lecture delivered at Cambridge University, 2nd February, 1971.) Pp. 34. (London: Scidge University Press, 1971.) 30p; $\$ 0.95$. Science Research Council. Report of the Working Party on High Temperature Processes. Pp. 36. (London Science Research Council. Report of the Working Science Research Council. Report of the Working
Party on Desalination. Pp. 40. (London: Scienco Research Council, 1971.) Gratis.
$[173$ Aslib. Occasional Publications. No. 6: The Distribution of Scientific and Technical Libraries and Users in Great Britain. By Alexandra Presanis. Pp. 32. £1.40. No. 7: Quantitative Data in Science and Technology. By Brenda Mountstephens, Averil Osborn and Margaret Slater. Pp. 24. £1.24. (London: Aslib, 1971.) [183 Department of Trade and Industry; Ministry of
Defence; and Joint Services Non-Metallic Research Board. A Review of the Science of Fibre Reinforced Plastics. By Dr N. G. McCrum. Pp. ix + 140. (London: HMSO, 1971.) £1.90. [183 National Museum of Wales. Sixty-third Annual Report 1969/1970. Pp. 135. (Cardiff: The Museum,
[1870.)

Race and Employment: Managing a Multi-racial Labour Force. By David Wainwright. Pp. 88. (London: Institute of Personnel Management, 1970.) f1. [183 Six Great Goals. By President Nixon. (State of tho
Union 1971, delivered to the US Congress, January 22, 1971.) Pp. 15. (London: US Information Service, 1971.)

The Geological Survey of Ireland. Bulletin No. 1, November 1970. Pp. 71. (Dublin: Department of Industry and Commerce, Geological Survey of Ireland,
1970.) $[183$
tics of

Department of Education and Science. Statistics of Education 1969. Vol. 4: Teachers. Pp. xviii +83.
(London: HMSO, 1971.)
¿1.70 net. (London: HMSO, 1971.) $£ 1.70$ net. 4183 Pollution Research and the Research Councils. Pp. 29. (London: Agricultural Research; Medical Research Council; Natural Environment Research Council; Science Research Council; Social Science
Research Council, 1971.) Research Council, 1971.) Experimental Work 1969. Pp. viii +101 . (Edinburgh: The Edinburgh School of Agriculture, 1970.) The Scottish Field Studies Association, Ltd. Annual Report for 1970 . Pp. $40+2$ plates. (Blair Drummond By Stirling: Scottish Field Studies Association, 1971. $35 \mathrm{p}$.

In the Public Interest: a Six-Part Explanation of BBC Policy. Pp. 27. (London: BBC, 1971.) [193 Institute of Linguists. Annual Report and Accounts for the year ended 31st July, 1970. Pp. 17. (London: The Institute of Linguists, 1971.)

\section{HOW TO BUY NATURE}

Volumes start in January, March, May, July, September and November, but subscriptions may begin at any time.

The direct postal price per subscription is:

12 MONTHS * (52 issues per title)

\begin{tabular}{lccc} 
& $\begin{array}{c}\text { Surface Mail } \\
\text { UK and } \\
\text { worldwide }\end{array}$ & \multicolumn{2}{c}{ Airfreight } \\
U.S.A. & Canada \\
Nature (Friday) & $£ 14$ & $\$ 48$ & $\$ 52$ \\
$\begin{array}{l}\text { Nature }+ \\
\text { Nature Physical Science }\end{array}$ & $£ 24$ & $\$ 83$ & $\$ 90$ \\
$\begin{array}{l}\text { Nature + } \\
\text { Nature New Biology }\end{array}$ & $£ 24$ & $\$ 83$ & $\$ 90$ \\
All three editions & $£ 29.50$ & $\$ 108$ & $\$ 116$ \\
Annual Index & $£ 1$ & $\$ 3$ & $\$ 3$
\end{tabular}

* Rates for shorter periods pro rata (minimum three months)

(Charge for delivery by air mail on application)
Editorial and Publishing Offices of NATURE

MACMILLAN JOURNALS LIMITED

4 LITTLE ESSEX STREET, LONDON WC2R 3LF

Telephone Number: 01-836 6633. Telegrams: Phusis London WC2R 3LF 711 NATIONAL PRESS BUILDING, WASHINGTON DC 20004

Telephone Number: 202-7372355 Subscription Department MACMILLAN JOURNALS LIMITED BRUNEL ROAD, BASINGSTOKE, HANTS

Telephone Number: Basingstoke $\mathbf{5 4 3 1}$

Advertisements only should be addressed to

T. G. SCOTT \& SON, LIMITED

1 CLEMENT'S INN, LONDON WC2A 2ED

Telephone 01-242 6264/01-405 4743

Telegrams: Textualist London WC2A 2ED

Registered as a newspaper at the Post Office

Copyright (C) Macmillan Journals Limited, April 9, 1971 